\title{
Family dynamics and social network of families of children with special needs for complex/continuous cares
}

\author{
Dinâmica familiar e rede social de famílias de crianças com \\ necessidades especiais de cuidados complexos/contínuos \\ Dinámica familiar y red social de niños familias con necesidades \\ especiales de cuidados complejos/continuos

\section{Beatriz Caroline Dias ${ }^{\mathrm{a}}$ \\ Sonia Silva Marcon ${ }^{b}$ \\ Pamela dos Reis ${ }^{b}$ \\ Iven Giovanna Trindade Lino ${ }^{b}$ \\ Aline Cristiane Cavicchioli Okido ${ }^{c}$ \\ Sueli Mutsumi Tsukuda Ichisato ${ }^{b}$ \\ Eliane Tatsch Neves ${ }^{d}$}

How to cite this article:

Dias BC, Marcon SS, Reis P, Lino IGT, Okido

ACC, Ichisato SMT, Neves ET.Family dynamics and social network of families of children with special needs for complex/ continuous cares. Rev Gaúcha Enferm. 2020;41:e20190178. doi: https://doi. org/10.1590/1983-1447.2020.20190178

\footnotetext{
autonomous Researcher. São Paulo, São Paulo, Brasil.

b Universidade Estadual de Maringá (UEM), Programa de Pós-graduação em Enfermagem. Maringá, Paraná, Brasil.

c Universidade Federal de São Carlos (UFSCAR), Programa de Pós-graduação em Enfermagem. São Carlos, São Paulo, Brasil.

Universidade Federal de Santa Maria (UFSM), Programa de Pós-graduação em Enfermagem. Santa Maria, Rio Grande do Sul, Brasil.
}

\section{ABSTRACT}

Objective: To describe the family dynamics and the social support network for families of children with special needs of multiple, complex and continuous care.

Methods: A descriptive study of a qualitative approach, carried out in Maringá - PR, having as theoretical and methodological reference the Calgary Model of Family Assessment (CMFA). Data was collected through semi-structured audio-video interviews, carried out in the homes, together with 11 family caregivers of 13 children.

Results: Data is presented in the following categories: structural, developmental and functional evaluation, which show the changes in the family routine and the needs for the adjustment of the roles of its members, in order to better implement the care at home.

Conclusions: Using the CMFA made it possible to identify and understand the composition, fragilities and potentialities of the family, as well as the relationships among its members and rearrangements to better enable care at home. This information favors interventions congruent with the needs of these families

Keywords: Child health. Social networking. Chronic disease. Family nursing. Family relations.

\section{RESUMO}

Objetivo: Descrever a dinâmica familiar e a rede social de apoio de famílias de crianças com necessidades especiais de cuidados múltiplos, complexos e contínuos.

Método: Estudo descritivo de abordagem qualitativa, realizado em Maringá - PR, tendo como referencial teórico e metodológico 0 Modelo Calgary de Avaliação da Família (MCAF). Dados coletados mediante entrevistas semiestruturadas audiogravadas, realizadas nos domicílios, junto a 11 cuidadores familiares de 13 crianças.

Resultados: Os dados estão apresentados nas categorias: Avaliação estrutural, de desenvolvimento e funcional, as quais mostram as mudanças na rotina familiar e as necessidades de readequação dos papéis de seus membros, para melhor implementação do cuidado no domicílio.

Conclusões: A utilização do MCAF possibilitou identificar e compreender a composição, fragilidades e potencialidades da família, bem como relações entre seus membros e rearranjos ocorridos para melhor viabilizar o cuidado no domicílio. Informações estas que favorecem intervenções congruentes com as necessidades dessas famílias.

Palavras-chave: Saúde da criança. Rede social. Enfermagem familiar. Relações familiares.

\section{RESUMEN}

Objetivo: Describir la dinámica familiar y la red social de apoyo de familias de niños con necesidades especiales de cuidados múltiples, complejos y continuos.

Métodos: Estudio descriptivo de abordaje cualitativo, realizado en Maringá - PR, teniendo como referencial teórico y metodológico el Modelo Calgary de Evaluación de la Familia (MCEF). Los datos se recolectaron por medio de entrevistas semiestructuradas audiograbadas, realizadas en los domicilios, junto a 11 cuidadores familiares de 13 niños.

Resultados: Los datos se presentan en las siguientes categorías: Evaluación estructural, de desarrollo y funcional, las cuales muestran los cambios en la rutina familiar y las necesidades de readecuación de los roles de sus integrantes, para una mejor implementación del cuidado en el domicilio.

Conclusiones: Utilizar el MCEF permitió identificar y comprender la composición, fragilidades y potencialidades de la familia, así como las relaciones entre sus integrantes y los reordenamientos implementados para viabilizar de mejor manera el cuidado en el domicilio. Esta información favorece intervenciones congruentes con las necesidades de estas familias.

Palabras clave: Salud del niño. Red social. Enfermería de la familia. Relaciones familiares. 


\section{口 INTRODUCTION}

Children with multiple, complex and continuous special care needs are those with severe chronic conditions resulting from health weaknesses and functional limitations that lead to the need for the use of life-sustaining technological devices as well as the frequent and continuous use of specialized health services ${ }^{(1-2)}$. These children require health care that can be classified as developmental, technological, medication, modified, and mixed ${ }^{(3-4)}$.

The population census of the Brazilian Institute of Geography and Statistics (Instituto Brasileiro de Geografia e Estatistica, IBGE) refers to this group as children with disabilities, however, in this research we chose the term children with special needs of multiple, continuous and complex care. This choice is based on international literature which understands that these children differ from children with disabilities because they require multiple demands for cares that go beyond the physical, mental, intellectual and sensory limitations, besides showing severe clinical conditions and intense use of resources and health services, not necessarily required by a child with disabilities ${ }^{(5)}$.

Caring for a child with special multiple, continuous and complex care needs causes changes in the family's structural organization, causing changes in its daily life and dynamics, which usually result in the redefinition of roles and the physical and emotional overload of some of its members, especially those most directly involved in care, usually the mother. Faced with this experience, the family goes through periods of adaptation in relation to the demand for care and (re) organization in favor of child care ${ }^{(4.6-7)}$. However, professionals are usually directed to biological aspects, being limited to providing guidance on the disease, promoting comfort and managing symptoms, not considering the family as a care unit ${ }^{(8-9)}$.

To this end, this study is based on the precepts of family-centered care, that is, the family of a child with special needs of multiple, complex and continuous care is an essential source of support and the main focus of attention is not the disease, but the child and their family ${ }^{(10)}$. In this direction, the Calgary Model of Family Assessment (CMFA) can be used by health professionals to understand family dynamics and relationships ${ }^{(11)}$ and, from this, offer quality care based on their needs in order to enhance family adaptation.

The CMFA is a theoretical and methodological model consisting of three main categories: i) structural, which analyzes the structure of the family as a whole - its formation, context and affective bonds; ii) development, which understands the changes and reorganization of families given the faxed situations and their trajectory; and iii) functional, which explores the interaction between individuals and their roles in the family system ${ }^{(11)}$. The application of this template allows to understand the family organization mode for care as well as to identify the support networks woven by the family. Its potential to favor interaction between family and professional is also added ${ }^{(11)}$.

Given the above, the objective of the study was to describe the dynamics and social support network of families of children with special needs of multiple, complex and continuous care.

\section{- METHOD}

This is a descriptive study with a qualitative approach. The Calgary Model of Family Assessment ${ }^{(11)}$ was used as a theoretical and methodological reference. The study included 11 family caregivers responsible for 13 children with special needs of multiple, complex and continuous care being monitored at a public educational institution specialized in rehabilitation located in a municipality in the interior of the state of Paraná.

The selection criteria for participation in the study were the following: being a family caregiver over 18 years old residing in the research municipality. Children with special needs for multiple, continuous and complex care were considered to be those who required at least two of the four care demands that characterize them: demand for developmental care for those children who need to be accompanied by professionals such as physical therapists, occupational therapists, among others; drug care, when the child depends on the continuous use of drugs; technological care, in which the child depends on some kind of technology to survive, such as mechanical ventilation, for example; and demand for modified usual care, related to the child's daily activities that should be performed in a special way and involving greater care and attention ${ }^{(3-4)}$. No exclusion criteria were adopted.

The production of empirical material took place in households between June and September 2015 from the elaboration of the genogram and ecomap, tools proposed by the CMFA, which graphically represent the family structure and the connections that exist between the family and society, whether positive or negative ${ }^{(11)}$. A semi-structured interview with the following guiding question was also used: Tell me about your family's experience of caring for a child with special care needs at home. The interviews lasted an average of 40 minutes, were audio recorded and later transcribed in full.

The graphic representations of each family were studied and analyzed according to the three dimensions submitted by the CMFA (structural, developmental and functional) ${ }^{(11)}$. 
The study was conducted in accordance with the ethical precepts of Resolution 466/2012 of the National Health Council, and was approved by the Standing Committee of Ethics in Research with Human Beings of the State University of Maringá (Opinion No. 083705/2014). To guarantee anonymity, the participating families are identified only by an Arabic number indicating the order of inclusion in the study.

\section{口 RESULTS}

As described above, the data were analyzed according to the three dimensions of the CMFA, for such, the displayed results were organized in this way.

\section{Structural evaluation}

In the structural evaluation there was investigated who are the individuals who are part of the family, their relationships and affective bonds. Thus, of the 11 families studied, five were characterized as a "core family", i.e., a family consisting of a couple together with their biological or adopted children (Families 4,6,8, 10 and 11); two were composed of a single parent and were characterized as a "single parent family" (Families 1 and 2); a "reconstituted family" when one of the parents establishes a new marital bond and there are children from previous marriages or relationships (Family 4); and two were "extended family" because grandparents and uncles lived in the same house (Families 7 and 9). It is noteworthy that in two families the child lived with the grandmother, who took care of her and raised her from birth, without the presence of parents (Families 3 and 5).

All family caregivers participating in the study were female, aged between 26 and 65 years old (with a mean of 36 years old). Most (nine) stopped working to take full care of the child. Aiming at helping the extended family with child care, one family moved into the same building as the extended maternal family, and three others moved out of town, one even residing in another state. Household income ranged from one to 12 minimum wages, and two children received the Continuing Provision Benefit (Families 1 and 3).

The 13 children with special, complex and continuous care needs were between 2 and 11 years old. Most (ten) were male. Two families had more than one child in this condition (Families 4 and 7) and Family 9 also had one child with Down Syndrome, which was not considered in this study because it was not characterized as a child with special needs for multiple cares, complex and continuous.

All demanded care for development, an expected result since they were recruited in a service that provides rehabilitation assistance (physiotherapy, speech therapy, among others). In addition, all required some modified usual care, such as diaper use, continuous monitoring of seizures and oxygen saturation, change of position to prevent injuries, among others. Table 1 displays the detailed characterization of these children.

Using Family 7 as an example, Figure 1 shows the genogram and ecomap constructs constructed with the participating families for the CMFA analysis. From the analysis of the figure, it is possible to observe the family structure of Family 7 , its internal relations and the community. It is possible to identify that maternal grandparents are the foundation for the caregiving mother and that the child's father participates little in the direct care process (Figure 1).

The structural dimension also assesses the external structure, that is, the establishment of bonds with people and institutions. In this sense, the external structure of the families participating in the study is mostly made up of health services, and leisure activities and the maintenance of a network of friends are uncommon. Families showed attachment to religiosity to face adverse situations and daily care, however, they did not usually attend religious institutions, which justify the exhausting routine they experience.

According to the caregivers, the child's physical condition makes it difficult to leave home, because besides the lack of accessibility, leaving meant bringing along appliances and many objects needed for care. Leaving without the child is also rare, only in extremely necessary situations, as many caregivers felt insecure to delegate the care of the child to other people, even being a close family member. In some cases however, the mother does not even have anyone to leave the child with. Contrary to most caregivers, Family 10 sought to take the child to different places such as cinema, shopping, playgrounds and recreation yard of the condominium where he lived, in order to provide socialization with other children.

As for the health services, the main element of the external structure for these families, it was observed that most of the families use the Basic Health Unit (BHU) only to acquire inputs and update the psychotropic prescriptions. No family reported receiving home visits from the Family Health Strategy team. It is noteworthy that although most families have low purchasing power, all children had a private health insurance, the co-participatory type, in which the family, in addition to paying the monthly fee, also pays a percentage previously established on the value of medical appointments and outpatient examinations.

However, not all families had a private plan for all their members and faced difficulties in accessing public services, which weakens the bond with them. In this sense, the Family 10 caregiver reported that she sought support for herself 


\begin{tabular}{|c|c|c|c|c|c|}
\hline Family & Gender & $\begin{array}{c}\text { Age } \\
\text { (Years old) }\end{array}$ & Medical diagnosis & Technological care & Drug-related care \\
\hline Family 1 & Male & 08 & $\begin{array}{l}\text { Hydrocephalus and } \\
\text { Cerebral palsy }\end{array}$ & $\begin{array}{l}\text { Ventriculoperitoneal } \\
\text { derivation - VPD }\end{array}$ & Anticonvulsant \\
\hline Family 2 & Male & 09 & $\begin{array}{l}\text { Cerebral palsy and } \\
\text { double hemiparesis }\end{array}$ & & \\
\hline Family 3 & Male & 07 & Cerebral palsy & Gastrostomy & $\begin{array}{l}\text { Sedative, } \\
\text { anticonvulsant, } \\
\text { antispasmodic } \\
\text { and antipsychotic }\end{array}$ \\
\hline Family 4 & Male & 11 & Not clarified & & $\begin{array}{l}\text { Sedative } \\
\text { and antipsychotic }\end{array}$ \\
\hline Family 4 & Male & 03 & Not clarified & & $\begin{array}{l}\text { Sedative } \\
\text { and antipsychotic }\end{array}$ \\
\hline Family 5 & Male & 02 & Not clarified & Gastrostomy & Gastric protector \\
\hline Family 6 & Male & 08 & $\begin{array}{l}\text { Myelomeningocele, } \\
\text { Megaesophagus } \\
\text { and Hydrocephalus }\end{array}$ & $\begin{array}{l}\text { Ventriculoperitoneal } \\
\text { derivation - VPD }\end{array}$ & Antipsychotic \\
\hline Family 7 & Male & 04 & $\begin{array}{l}\text { Cerebral palsy and } \\
\text { West Syndrome }\end{array}$ & & $\begin{array}{l}\text { Anticonvulsant, sedative } \\
\text { and antiemetic }\end{array}$ \\
\hline Family 7 & Male & 04 & $\begin{array}{l}\text { Cerebral palsy } \\
\text { and Epilepsy }\end{array}$ & & $\begin{array}{l}\text { Anticonvulsant, sedative } \\
\text { and antiemetic }\end{array}$ \\
\hline Family 8 & Female & 02 & $\begin{array}{l}\text { Hydrocephalus } \\
\text { and Myelomeningocele }\end{array}$ & $\begin{array}{l}\text { Ventriculoperitoneal } \\
\text { derivation - VPD and } \\
\text { bladder catheter relief } \\
\text { - BCR }\end{array}$ & $\begin{array}{l}\text { Antispasmodic and } \\
\text { prophylactic antibiotic }\end{array}$ \\
\hline Family 9 & Female & 03 & $\begin{array}{l}\text { Shwartz } \\
\text { Jampel Syndrome }\end{array}$ & BIPAP and Venturi Mask & $\begin{array}{l}\text { Sedative } \\
\text { and antipsychotic }\end{array}$ \\
\hline Family 10 & Male & 10 & Unclear Hypomelanosis & & $\begin{array}{l}\text { Sedative } \\
\text { and anticonvulsant }\end{array}$ \\
\hline Family 11 & Female & 04 & Microcephaly & & $\begin{array}{l}\text { Sedative, } \\
\text { anticonvulsant, } \\
\text { antispasmodic, } \\
\text { cannabidiol, } \\
\text { gastric protector } \\
\text { and antiemetic }\end{array}$ \\
\hline
\end{tabular}

Chart 1 - Characterization of the children with special needs for multiple, complex and continuous cares. Maringá - PR, 2015 Source: Research data, 2015. 


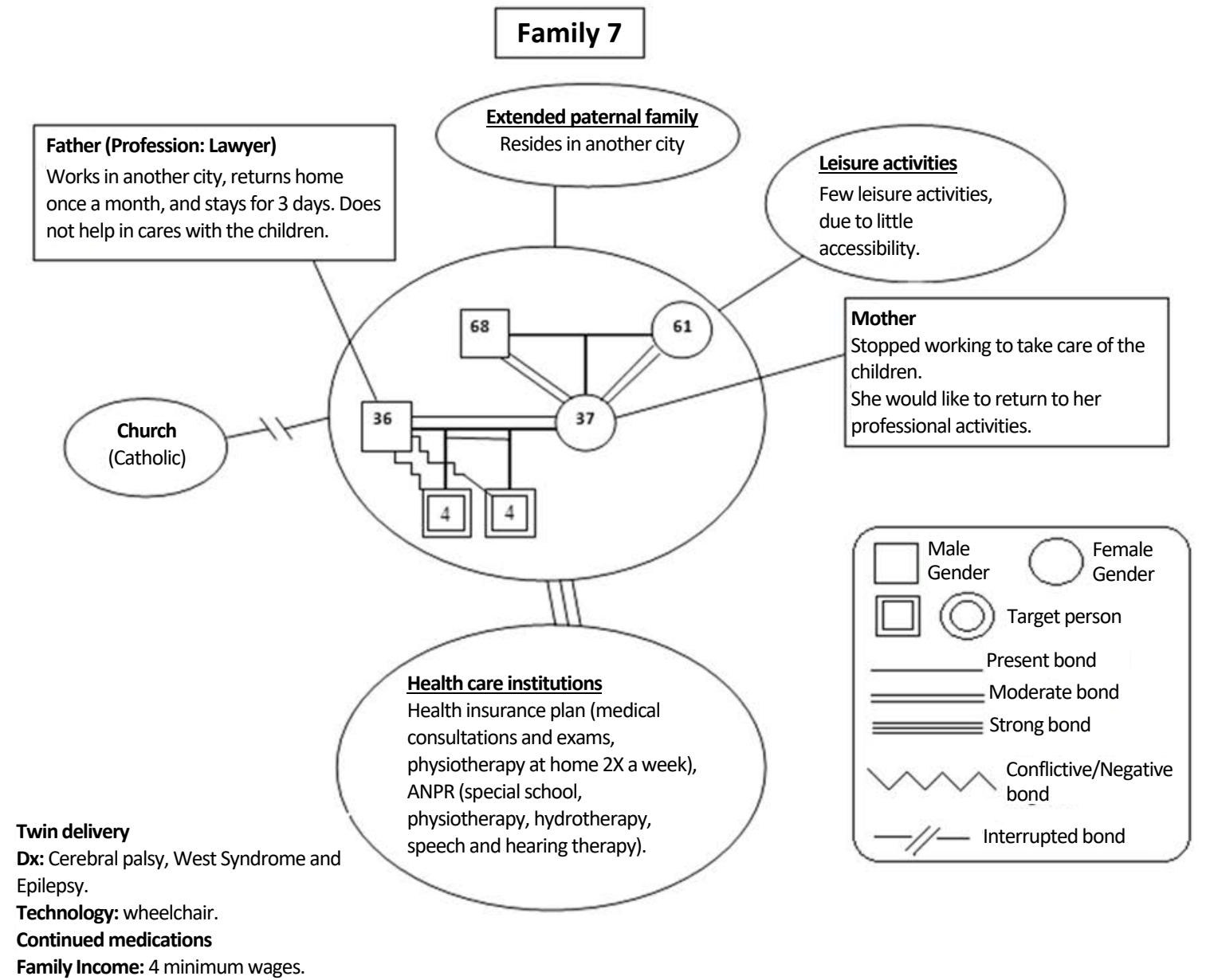

Figure 1 - Genogram and ecomap: Family 7. Maringá - PR, June 2015

Source: Research data, 2015.

in the psychology service of the BHU, but the service hours were inflexible, which made it difficult to travel to her. She also reported that the professional who attended her was indifferent to her condition, leaving her discouraged to continue attending the service. In contrast, the Family 2 caregiver revealed that she sought help from the Reference Center for Social Assistance (Centro de Referência de Assistência Social, CRAS) because she was suffering domestic violence from her alcoholic husband. She also said that the husband's behavior was negatively influencing the children, who began to show aggression and agitation at school. The professionals at this service have warmly guided her and become an important component of her social support network.

The neighborhood was also mentioned as a support network. In this direction, the caregivers of Families 5 and 6 reported that they could count on neighbors to leave the child when they needed to go out or even to prepare lunch and care for the other children. In addition, some caregivers stressed the importance of exchanging experience with the parents of other children.

\section{Developmental evaluation}

In assessing the development dimension, we seek to understand the transformations in family organization over time, according to the context of the family life cycle. Thus, in most of the families studied, all members mobilized to ensure the necessary care for the child, from the oldest healthy children to the extended family, especially in the performance of domestic activities. In Family 9, the grandmother quit her job to take full care of the child while the child's parents continued their work activities.

The child in Family 11 remained at home all day, did not attend school due to convulsive seizures that were difficult to control. However, the family was reorganized to prioritize child care without any of the members leaving paid work. 
Thus, the mother worked during the day and took care of the child at night, the father worked in the morning and evening and took care of the child in the afternoon, in turn, the maternal grandmother worked in the afternoon and took care of the child in the morning. Only the paternal grandfather did not participate in the rotation of care with the child, but acted as support for all.

Over time the context of the family life cycle changes, requiring constant reorganization. Thus, over the years, children grow and become heavier. This is a common situation among families, who need to seek new strategies to ensure the continuity of daily care that was easily performed when the child was younger; the bath, for example. In this study, six families reported the difficulty in performing some basic daily activities due to the child's growth.

\section{Functional evaluation}

This dimension details the way individuals behave with each other. Regarding the way individuals relied on each other to cope with daily demands, it was found that mothers/ grandparents were mainly responsible for taking care of the children, taking them for exams, consultations. and therapies complementary to treatment and also by household chores. In most cases, the father did not help in caring for the child and in others, the father figure remained distanced. It is noteworthy that two mothers believed that the father of the child did not even need to assist in care, since it already provided for the household.

Two caregivers experienced child care in isolation, had no established relationship with the child's father and/or extended family (Families 2 and 10). In two cases, grandparents assumed the role of primary caregivers due to the abandonment and rejection of biological parents (Families 3 and 5).

According to the Family 11 caregiver, the relationship with the husband was affected because the established routine made it impossible to cultivate intimacy as a couple. Other caregivers complained about the father's little affective interaction with the child, a situation that bothered them a lot, especially for the Family 7 caregiver.

\section{DISCUSSION}

According to the results, all family caregivers were mothers or grandmothers, reaffirming the historical and ideological context that care responsibility is centered on females ${ }^{(12)}$. In the same vein, a study that aimed to describe and discuss, from the perspective of gender theories, the places of the family's responsible persons in providing care and material support for children and adolescents in a mental health service reinforces the hegemony of the family. traditional notion of the feminine as a place of care even in cases where the woman is responsible for the financial provision. The authors highlight the importance of raising awareness about the possibility of care being exercised by both sexes and non-naturalized as a task of the female universe ${ }^{(13)}$.

In two cases, the parents abandoned their children and they were taken care of by their grandparents. A similar situation is commonly reported in the literature, however, the poorer health associated with advanced age is cause for concern as to who will take care of the child if they become disabled or die, and it is important to expand the support network of these families in order to prevent the helplessness of these children if their grandparents are unable to care ${ }^{(14)}$.

The results of a Canadian study that investigated how families care for children with complex health needs resemble the results in this investigation. According to the authors, this is a laborious condition that requires family readiness to provide care at any time, so parents cannot have minimum time to meet their individual needs, such as holidays and intimate time between the couple ${ }^{(15)}$. The authors also state that men shared responsibilities, taking turns in performing the necessary duties related to the care of their children with complex needs, not corroborating the findings in this study.

In this investigation, all families acquired a private health plan for the child and the link with the health units near the residence was weakened. This result is in line with a research that sought to understand and identify the support and social network from the perspective of families of children with chronic conditions, which identified difficulties in relation to the Unified Health System, as the care offered is slow and bureaucratic ${ }^{(16)}$. In the same vein, a qualitative study conducted with 12 family caregivers of children and adolescents with chronic disease also revealed difficulties in building a permanent partnership between family and health team, with constant caregiver complaints prevailing ${ }^{(17)}$.

There were also reports that showed that some families were not instrumental to take care of the child at home, which hinders the performance of care, besides raising the feeling of overload. Thus, the burden of family caregivers may be related to the lack/absence of instrumentation to assume daily and intermittent care with the child. This is because health professionals themselves are not adequately prepared for holistic care and family-centered needs, and ultimately represent a support network capable of providing emotional support to parents and caregivers, especially mothers, who are primarily responsible for the care. comprehensive care of these children ${ }^{(18)}$. 
In this sense, the importance of neighbors and other parents of children with special health needs is often revealed in studies of this nature. This is a proper support network with people who also experience a similar situation through the exchange of useful experiences and information that facilitate access to health services and constitutional rights ${ }^{(19)}$.

The CMFA provided visibility and understanding of the family organization, resources, and support networks of families of children with special, complex, and continuous care needs studied. According to the literature, such an approach allows us to understand the family as a care unit and not only as the sum of the individuality of each family element, in different contexts ${ }^{(20)}$. It is a little used and valued reference, but it can greatly contribute to nursing in family care ${ }^{(20)}$.

Nursing, in its turn, by appropriating this model, recognizes the weaknesses and potentialities of each family and thus can intervene in such a way as to enhance the empowerment of families of children with special, complex and continuous care needs ${ }^{(3)}$. The actions must go beyond the specialized technical procedures, the nursing needs to bond, counsel and support the family, so as to enhance their ability to provide care and enable the development of skills necessary for this practice(8).

\section{口 FINAL CONSIDERATIONS}

In this study, we aimed to describe the dynamics and social support network for families with children with special needs of multiple, complex and continuous cares and we consider that the displayed results achieved the proposed objectives. Although all the families studied were experiencing a seemingly similar situation, each context expressed its particularity. In general, one highlights the expressive participation of the extended maternal family, the maladjustments in the marital relationship and the restricted access to leisure spaces. In addition, some negative experiences with public health services and the majority adherence to private health plans are highlighted.

We consider as a limitation of this study the cross-sectional design, indicating the need for longitudinal studies on this theme.

\section{REFERENCES}

1. McPherson MG, Arango P, Fox H, Lauver C, McManus M, Newacheck PW, et al. A new definition of children with special health care needs. Pediatrics. 1998;102(1 Pt 1):137-40. doi: https://doi.org/10.1542/peds.102.1.137
2. Esteves JS, Silva LF, Conceição DS, Paiva ED. Families' concerns about the care of children with technology-dependent special health care needs. Invest Educ Enferm. 2015;33(3):547-55. doi: https://doi.org/10.17533/udea.iee.v33n3a19

3. Dias BC, Ichisato SMT, Marchetti MA, Neves ET, Higarashi IH, Marcon SS. Challenges of family caregivers of children with special needs of multiple, complex and continuing care at home. Esc Anna Nery. 2019;23(1):e20180127. doi: https://doi.org/10.1590/2177-9465-ean-2018-0127

4. Cabral IE, Moraes JRMM. Family caregivers articulating the social network of a child with special health care needs. Rev Bras Enferm. 2015;68(6):769-76. doi: https://doi.org/10.1590/0034-7167.2015680612i

5. Cohen E, Kuo DZ, Agrawal R., Berry JG, Bhagat SK, Simon TD, et al. Children with medical complexity: an emerging population for clinical and research initiatives. Pediatrics. 2011;127(3):529-38. doi: https://doi.org/10.1542/peds.2010-0910

6. Reis KMN, Alves GV, Barbosa TA, Lomba G0, Braga PP. A vivencia da família no cuidado domiciliar à criança com necessidades especiais de saúde. Cienc Enferm. 2017;23(1):45-55. doi: https://doi.org/10.4067/S0717-95532017000100045

7. Góes FGB, Cabral IE. Discourses on discharge care for children with special healthcare needs. Rev Bras Enferm. 2017;70(1):154-61. doi: https://doi. org/10.1590/0034-7167-2016-0248

8. Cruz CT, Zamberlan KC, Silveira A, Buboltz FL, Silva JH, Neves ET. Atenção à criança com necessidades especiais de cuidados contínuos e complexos: percepção da enfermagem. REME - Rev Min Enferm. 2017; 21:e-1005. doi: https://doi.org/10.5935/1415-2762.20170015

9. Svavarsdottir EK, Sigurdardottir A0, Tryggvadottir GB. Strengthsoriented therapeutic conversations for families of children with chronic illnesses: findings from the Landspitali University Hospital Family Nursing implementation project. J Fam Nurs. 2014;20(1):13-50. doi: https://doi. org/10.1177/1074840713520345

10. Mikkelsen G, Frederiksen K. Family-centred care of children in hospital-a concept analysis. J Adv Nurs. 2011;67(5):1152-62. doi: https://doi.org/10.1111/j.13652648.2010.05574.x

11. Wright L, Leahey M. Enfermeiras e famílias: guia para avaliação e intervenção na família. $5^{a}$ ed. São Paulo (SP): Roca; 2012.

12. Alves JP, Costa LHR. Mães que cuidam de filho (a)s com necessidades especiais na perspectiva de gênero. Rev Eletr Gestão Saúde. 2014[cited 2019 Sep 15];5(3):796-807. Available from: https://pdfs.semanticscholar.org/5215/ e1b3352ddc0694995954a8bcdc91cc3b2957.pdf

13. Muylaert (J, Delfini PSS, Reis AOA. Relações de gênero entre familiares cuidadores de crianças e adolescentes de serviços de saúde mental. Physis: Rev Saúde Coletiva. 2015;25(1):41-58. doi: https://doi.org/10.1590/S010373312015000100004

14. Matsukura TS, Yamashiro JA. Intergenerational relationships, support practices and daily life of families of children with special needs. Rev Bras Educ Espec. 2012;18(4):647-60. doi:https://doi.org/10.1590/S1413-65382012000400008

15. Woodgate RL, Edwards M, Ripat JD, Borton B, Rempel G. Intense parenting: a qualitative study detailing the experiences of parenting children with complex care needs. BMC Pediatr. 2015;15:97. doi: https://doi.org/10.1186/s12887015-0514-5

16. BarbosaTA, Reis KMN, Lomba GO, Alves GV, Braga PP. Support network and social support for children with special health care need. Rev Rene. 2016;17(1):60-6. doi: https://doi.org/10.15253/2175-6783.2016000100009 
17. Nóbrega VM, Reichert APS, Viera CS, Collet N. Longitudinality and continuity of care for children and adolescents with chronic diseases. Esc Anna Nery. 2015 [cited 2019 Feb 13];19(4):656-63. Available from: http://www.scielo.br/scielo. php?pid=S1414-81452015000400656\&script=sci_arttext\&tIng=en

18. Severo VRG, Santos RP, Neves ET, Ribeiro CF. Conhecimento prévio de cuidadoras de crianças com necessidades especiais de saúde: uma abordagem freiriana. Cienc Cuid Saude. 2019;18(3):e46351. doi: https://doi.org/10.4025/ cienccuidsaude.v18i2.46351

19. Musquim CA, Araújo LFS, Bellato R, Dolina JV. Genograma e ecomapa: desenhando itinerários terapêuticos de família em condição crônica. Revista Eletr Enf. 2013;15(3):656-66. doi: https://doi.org/10.5216/ree.v15i3.17730
20. Monteiro GRSS, Moraes JCO, Costa SFG, Gomes BMR, França ISX, Oliveira RC. Aplicación del Modelo Calgary de Evaluación Familiar en el contexto hospitalario y en la atención primaria a la salud. Revisión integradora. Aquichan. 2016;16 (4):487-500. doi: https://doi.org/10.5294/aqui.2016.16.4.7

\section{Acknowledgments:}

To CAPES for the master's scholarhsip granted to the lead author.

\section{- Corresponding author:}

Sonia Silva Marcon

E-mail: soniasilva.marcon@gmail.com

\section{Associate editor:}

Rosana Maffacciolli 


\section{Erratum of article:}

Dias BC, Marcon SS, Reis P, Lino IGT, Okido ACC, Ichisato SMT, Neves ET. Family dynamics and social network of families of children with special needs for complex/continuous cares. Rev Gaúcha Enferm. 2020;41:e20190178. doi: https://doi.org/10.1590/1983-1447.2020.20190178

\section{On page 1, Authors:}

where it reads:

Beatriz Carolina Dias

\section{should read:}

Beatriz Caroline Dias 